\title{
English Function by Waiters and Waitress at Flames Cafe and Restaurant in Sanur Area
}

\author{
Kiki Nurwahyuni ${ }^{1}$, Oswaldus $\mathrm{Wegu}^{2}$, Ketut Sudrama ${ }^{3}$ \\ Universitas Warmadewa Denpasar-Bali, Indonesia ${ }^{1,2,3}$ \\ \{sudrama@gmail.com³ ,oswaldus.wegu@gmail.com²
}

\begin{abstract}
The study aims to analyze the types of English function between the foreigners tourist and staff by utilising theory of the function of language proposed by Halliday and function of English by Jones. The data were collected from the conversation between waiters and waitress at Restaurant with guest. This study is designed by using descriptive qualitative approach which are all of the data are collected and classified based on the function of English and English expression. The results show that English used by waiters and waitress at Flames Cafe and Restaurant Sanur area, are: greeting, inviting someone, suggesting, giving information, requesting, apologizing, thanking, saying goodbye. They used communicative function verbal or directly and their more practice using English when they give services, because all the staff using expression with good English and say it politely and clearly. Thus, it can be concluded that most of function of English and their expressions used mostly out of rule. Also, the sentence that they used is ungrammatical, however, the point of their conversation while serving those guests can be recognizable.
\end{abstract}

Keywords: Language used; English function; waiters and waitress; Sanur Area

\section{Introduction}

Generally, language is a means to make a conversation to the others, without language, people will be hard to do some activities. Language as a tool of communication has a lot of function, for example language can express one idea or parts of every activities. The function of language can be viewed from the basic and the motive of its development. Language as a means ourselves expression, language is also used to express all our mind. In this case language in used to attract one's attention. Function of language has often figured out prominently in linguistic research; language is used. Among other thing, it would be helpful to be able to establish some general principles thing to use of language; and this is perhaps the most usually interpretation of the concept of a functional approach [1].

Likewise, [2] in all language, people who speak in formal language are quietly different from informal language. Usually, we use formal language to foreigners, president, and to someone who has a high level than us. While informal language frequently used to fellows student, classmate, our families and so on. However, formal or informal language is not always bid deal as long as speakers use it into right topics, situation, and interlocuters feel happy. 
Related to formal and informal language, the following expression or phrases shown us, for instance, Sorry gotta go, Wana beer. Those expressions are informal language that usually used in the cafe. It might be considered for this expressions, I'm afraid I have to go now, Could I offer you a beer [2]. It is formal language which is more polite and could be express in the formal situation. Those expression above show that languages can be classified based on the context. However, sometimes people tend to use informal language as a form of having close relationship among families or friends. Besides that people prefer to convey relaxed pronunciation which will be easy to be understood in formal and informal situations. Instead of language which has a role as the instrument of control also has the other side as well. It since the kid is very much aware that language is additionally methods where by other exercise control of him. Firmly identified with the instrument model, it can be assumed as a regulatory model language. By this, language means to the use as way of people to regulate their behavior as well. This without anyone will not curse it, because of language which has numerous other capacities, instead of many plating and take control of the climate. In any case, it bore minimal evident connection to any utilized of language, in any event to any with which the small kid is natural [1]. The explanation of language definition which has been defined above, in fact language has a very important role in society. It showed that no one can live perfectly without using the language because it relates to the all parts of human life. Even though language is important, but it is really difficult or even impossible for anyone to have capability in all languages in this world. But also it is impossible for someone to know all of the language in this world, even if he/she spends all of the life time in learning language.

Language in every nations are various, for example, Indonesia has various dialects in every regions such as Javanese, Balinese, Buginese, Manado Malay, Acehnese and so on. Besides the existence of language varieties, there is metaphorical language. In metaphorical language has language functions which are very complex, and has so many inter relationship with various aspect of human life that can be student from numerous points of view.

The following are relevant researches which concerned to English function study such as Ahmmed, Sinha, Khan, \& Islam (2020); Chauvin, Fenouillet, \& Scott Brewer (2020); Giri (2014); Thompson \& Khawaja (2016). Moreover, [3] that EFL is being utilized for EIL purposes to encourage correspondence between foreign speaker. It infers that it necessaries to concentrate on interpretability to get student ready for diversity of languages that they are probably going to experience outside the EFL classroom. In line with [8] found that English in Indonesia still as foreign language and never acknowledged as second language (SL), moreover Indonesian still used as national language. Then, [9] stated English spelling is widely investigated, but little is known about spelling in English as an additional language (EAL), especially in the context of text production. Relating to English function used by waiters and waitress at Flames Cafe and Restaurant in Sanur Area, which all customers are coming from abroad, should be able to speak in English well to those guests while serving. In fact, all the staff are capable in communicating to guests. It is proved by visitors who felt comfortable in doing communication to staff. Therefore, based on that background, this study aims to analyze the types of English function between foreigner and staff.

\section{Methods}

This study is designed in qualitative approach. This research site at Flames Cafe and Restaurant. This location very famous in Sanur area, Denpasar regency, Indonesia since the 1999 until now and this place as one of the favorite for foreign guests. It is a unique place for 
refreshing mind because this place was made of bamboo and the reeds roof stacked construction neatly and very cool. Then, the data source were taken from conversation between waiters and waitress staff. In collecting the data, researcher used observation technique and tape recorder and then taking note. Also, researcher as a key instrument goes to field and does some activities, firstly recorded and observed the conversation between waiters and waitress staff with guests and then listened to conversation from the recording. After collecting the data, researcher analyzed it descriptively by focusing on expression that waiter and waitress used based on their conversion done and then interpreted the data by giving some relevant examples.

\section{Result and Discussion}

The function of English used by waiter and waitress and the guest found various functions. The following is the description of the conversation of waiter and waitress and the guest that taken based on the real situation.

Function of English and English Expression Used by Waiters and Waitress Staff at Flames Cafe and Restaurant

\section{Greeting}

These expression could be formal and informal. From all of the staff or the respondent of this research, almost all of them could use this in a good way.

$\begin{array}{ll}\text { Elfrit } & : \text { Good morning, welcome to Flames Cafe and Restaurant. } \\ \text { Martin } & : \text { Good morning thank you } \\ \text { Elfrit } & : \text { Hello, morning sir } \\ \text { Martin } & : \text { Morning } \\ \text { Pak Ian } & : \text { Welcome in our restaurant } \\ \text { Tommy } & : \text { Thank you } \\ \text { Pak Ian } & : \text { How are you..? } \\ \text { Tommy } & : \text { I'm very well, thank you. Can I see the menu? } \\ \text { Pak Ian } & : \text { Yes, set down here, please? } \\ \text { Tommy } & : \text { Sure... thank you. } \\ \text { Pak Ian } & : \text { Wait a moment I will take the menu for you. } \\ \text { Tommy } & : \text { Thank you very much }\end{array}$

The underlined expression that stated by 'Pak Ian', "welcome to Flames Cafe and Restaurant" is formal sentence and classified into greeting function. The waiters and waitress staff always uses this expression while standing in front of Restaurant when the guest or tourism passed in front of the Restaurant. This expression said politely and friendly. The other expression that including in greeting function also used to greet the guest. The English is used to greet the guest above is informal expression. It was informal expression because the greeting expression is used in informal English such as "Hello good morning sir" it was done when there was a guest came passing in front at Restaurant. Besides that, staff used other language like gesture, for example when they said "Welcome to our Restaurant" to guest or tourism passing in the front of restaurant or they are coming to have breakfast, lunch, or dinner. They said it by smiling in their face. Those expressions above showed the politeness for the purpose of hospitality. 


\title{
a) Inviting Someone
}

This expression was used to invite someone to do something. By doing this expression, those tourist came to the restaurant

Elfrit: $\quad$ Good morning, sir. Would you like to see our menu for lunch or dinner and then see the restaurant?

\author{
Martin : Good morning, yes. Thank you. \\ Elfrit : Good afternoon sir. \\ Martin $\quad$ :Good afternoon, do you have snack or something else. \\ Elfrit : No, we have hot chips. Yes, would you like to see our menu..? \\ Martin : Thanks.
}

From the conversation above, there is expression shows inviting someone. The underline word above is the way how the staff invited the guest to see the menu in their restaurant. Then, spontaneously, the guest answered through formal expression. It is caused the waiters called 'sir' to the guest and followed by saying "would you like to see our menu for lunch or dinner and see our restaurant." This is one of the way how the staff spoken more politely and also the staff gives smiles when invited the guest.

Pak Ian : Yes please, come inside, now we have special menu for this week.

Tommy : what kind of special menu you have?

In the conversation above, there is language function shows inviting someone. But in this case, the staff used informal expression. It can be seen from the underline word, the staff only said "yes please come inside. Actually should be "would you like come inside?"
Pak Ian : Would you like to see our menu
Mr. Mark : Maybe, no.
Pakian :Ooh. Thank you
Mr. Mark : (only looked the menu and gone)

In the conversation above, it shows expression offering something between the staff and guest. It can be seen from the underline sentence above "would you like..."? It indicates that the waiter used formal expression to the guest more polite and respect the guest.

\section{b) Suggesting}

Suggesting is the function of English used by peoples to give some suggestions to other.

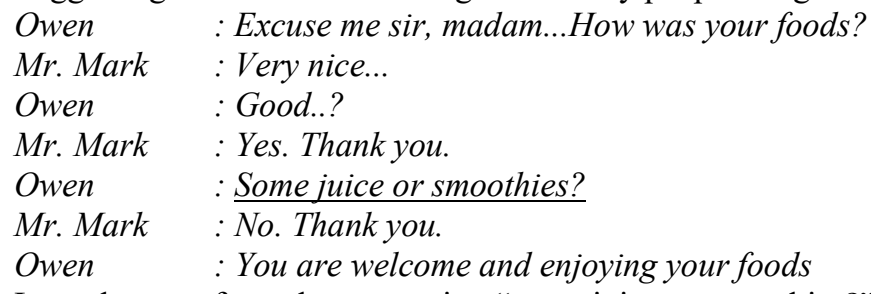

It can be seen from the expression "some juice or smoothies?" which this language function is offering. This expression including informal English because the expression is used by staff ungrammatically. Consider with the formal English expression "would you like to have some juice or smoothies?

$\begin{array}{ll}\text { Elfrit } & : \text { Hello. Good evening sir } \\ \text { Martin } & : \text { Good evening } \\ \text { Elfrit } & : \text { Yes please, seat dawn this table } \\ \text { Martin } & : \text { Thank you }\end{array}$


Elfrit $\quad:$ would you like some drink beer bintang or coca cola?

Martin : Yes one bintang and one coca cola, please.

Elfrit $\quad$ :Yes sir.

Martin : Thank you very much

The conversation above shows formal English. The sentence "would you like some drink beer bintang or Coca Cola?" This English function is classified into offering. It seems from the staff in suggesting cool drink to the guest and the staff convey it into formal English "would" when the staff was offering the drinks and it is using correct grammatically.

\section{c) Giving Information}

Giving information means that sharing or spread out the information to the other.

Martin : So give tell me, how to get to the beach from here.

Elfrit $\quad:$ You go this way turn left and you will find police office, you will turn right.

Martin : And the beach in the back.

Elfrit :Yes ma'am.

Martin : Thank you so much

The underline sentence is the expression of giving information. The tourist does not know the beach and they always ask with the waiters and waitress staff at restaurant. The waiters and waitress using English formal expression and explain to them accurately and politely and then waiters and waitress is using interpersonal category in giving information to each other.

\section{d) Requesting}

$\begin{array}{ll}\text { Elfrit } & \text { : Welcome in our restaurant } \\ \text { Martin } & \text { : Thank you } \\ \text { Elfrit } & \text { : How are you..? } \\ \text { Martin } & \text { : I'm very well, thank you. Can I see the menu? } \\ \text { Elfrit } & \text { : Yes, set down here, please? } \\ \text { Martin } & \text { : Sure. Thank you } \\ \text { Elfrit } & \text { : Wait a moment, I will take the menu for you. } \\ \text { Martin } & \text { : Thank you very much. }\end{array}$

From conversation above, it can be seen from underline words that this is a language function and classified as requesting. The waiters and waitress requested to do something for own good. The language used is English standard. It is similar [10] mentioned, "He invited me to lunch with him". Most the staff of Flames Cafe and Restaurant requested the visitors in a polite way. In order to realize a good service to the guest, staff could use the requesting expression without difficulties.

$\begin{array}{ll}\text { Elfrit } & : \text { Welcome in our restaurant } \\ \text { Martin } & : \text { Thank you. } \\ \text { Elfrit } & : \text { How are you? } \\ \text { Martin } & : \text { I'm very well, thank you. Can I see the menu? } \\ \text { Elfrit } & : \text { Yes, set down here, please? } \\ \text { Martin } & : \text { Sure. Thank you } \\ \text { Elfrit } & : \text { Wait a moment I will take the menu for you. } \\ \text { Martin } & : \text { Thank you very much. }\end{array}$

From the conversation above, this is a language function which is include as expression requesting. It can be seen from the underline words, the waiters and waitress requested to do 
something for own good. Most of the staff of Flames Cafe and Restaurant requested the staff in a polite way. In order to realize a good service to the guest, staff could use the requesting expression well.

\section{e) Apologizing}

Elfrit $\quad:$ Excuse me, are you ready to order, sir?

Martin :Yes, ok. Sorry I want to take one Fanta strawberry!

Elfrit $\quad:$ I'm sorry, Fanta Strawberry already finish.

Martin : It's ok

Elfrit : We have Coca-Cola, Sprite, light Coca.

Martin : Two Coca-Cola

Elfrit : Ok... two Coca-Cola

Martin : One chicken cordon blue, one carbonara chicken and bacon pasta

Elfrit: $\quad$ Ok, sir, I will repaid again 2 coca-cola, one chicken cordon blue, cabonara chicken and bacon pasta.

Elfrit : Thank you.

The expression "I'm sorry" that is a kind of apologizing expression. This expression is commonly responded by another speaker by using 'it's ok'. When the apologizing expression is responded by that words, it is showed that the guest or the speaker is accepting your apology and it shows that everything is all right.

\section{f) Thanking}

Pak Ian : Thank you very much for coming ma'am.

Mr. Mark : Thank you.

Pak Ian : you are welcome ma'am. I really hope you come again in our restaurant.

In this conversation, the waiter used an English function expression by showing formal expression. It can be seen from the underline words. The waiters say thank for their presence and also hope they come again.

\section{g) Saying Goodbye}

Commonly, saying goodbye used by people when they will leave. In this case, they are some formal expressions and informal expressions relating to saying goodbye. In saying goodbye to someone we should say it politely and friendly.

Owen : Goodbye, see you again madam

Tommy : : See you (the guest leave the restaurant)

On the conversation above, the underline sentence belongs to saying goodbye function, and it includes formal way. Hereby, the staff used the words "Goodbye, see you again". The conversation above shows that the guest leave the restaurant and the staff said goodbye to the guest by saying goodbye, see you letter. In saying goodbye, the guest also waved her hand and leave the restaurant.

\section{Conclusion}


Grounded by the research result, found that function of English used by waiters and waitress at Flames Cafe and restaurant that are: greeting, inviting someone, suggesting, giving information, requesting, apologizing, thanking and saying goodbye. Commonly, greeting is an expression which is used by peoples to greet or establish contact with their friends. This expression also used to begin a conversation or open a discussion. Then, inviting someone is an expression to get someone to do something. Suggesting is an English function used by people to suggest or recommend something to someone. Moreover, giving information is an English function which is used to share or spread out the information to someone. Requesting is a English function that is used to ask someone to do something for us. Apologizing is an expression which is used when someone something wrong. Thanking is an expression frequently used when someone has done something for us. Saying goodbye is one of English functions which is used when we want to leave other people. In this case, the staff used English language directly and they practice their English while serving those guests into formal expression clearly and politely. Besides that, there are some staff still speak into informal English language but does not reduce the content of the message they want to convey to the guests.

\section{References}

[1] M. A. K. Halliday, Exploration in the Function of Language. London: Edward Arnold, ltd, 1973.

[2] T. Bruce, Speaking Naturally. Cambridge: University Press, 1985.

[3] S. James Nicholson, "English as an International Language: A Functional Role in South Korea," J. Study English Linguist., vol. 3, no. 1, p. 13, 2015.

[4] R. Ahmmed, B. S. Sinha, D. R. Khan, and D. M. Islam, "A Needs Analysis of Maritime English Language Skills for Bangladeshi Seafarers to Work on-board Ships," Mar. Policy, vol. 119, no. February, p. 104041, 2020.

[5] R. A. Giri, "Changing Faces of English: Why English is not a Foreign Language in Nepal," J. World Lang., vol. 1, no. 3, pp. 192-209, 2014.

[6] A. S. Thompson and A. J. Khawaja, "Foreign Language Anxiety in Turkey: the Role of Multilingualism," J. Multiling. Multicult. Dev., vol. 37, no. 2, pp. 115-130, 2016.

[7] R. Chauvin, F. Fenouillet, and S. Scott Brewer, "An Investigation of the Structure and Role of English as a Foreign Language Self-Efficacy Beliefs in the Workplace," System, vol. 91, p. 102251, 2020.

[8] A. Lauder, "the Status and Function of English in Indonesia: a Review of Key Factors," Makara Hum. Behav. Stud. Asia, vol. 12, no. 1, p. 9, 2008.

[9] B. Arfé and R. L. Danzak, "The Influence of First Language Spelling and Response Inhibition Skills on English-as-an-Additional-Language Spelling,” Cogn. Dev., vol. 56, no. September, pp. 1-14, 2020.

[10] A. V. Thomson, A, J and Martinet, A Practical English Grammar. London: Press, University, 1986. 